Proceeding ICOGISS 2019

Page 820-837. ISBN: 978-602-6 988-75-1

Web Jurnal Online: jurnal.unmuhjember.ac.id

By: Indar Arifin

Analysis Of The Relationship Between Local Government Bureaucracy And Society Mode

In The Process Of Social And Political Change In Wajo Regency

\title{
ANALYSIS OF THE RELATIONSHIP BETWEEN LOCAL GOVERNMENT BUREAUCRACY AND SOCIETY MODEL IN THE PROCESS OF SOCIAL AND POLITICAL CHANGE IN WAJO REGENCY
}

\author{
Indar Arifin \\ Prodi Ilmu Pemerintahan FISIP Universitas Hasanuddin Makassar \\ indararifin123@yahoo.co.id
}

\begin{abstract}
The aims of the study are to explain, to analyze, and to find a relationship model between government bureaucracy and society in the process of social and political change in Wajo regency. Data collection methods used in this study were Focus Group Discussion (FGD), documentation, intensive interaction, in depth interview and other instruments. Samples were selected by purposive and snowball methods. Informants in this study are both from internal and external bureaucracy. Internal bureaucracy informants consisted of; (1) strategic apex (top-level management), (2) middle line (chief executive), (3) operating core (executant), while the external bureaucracy informants can be classified into four groups; (1) local elite which consist of local figures and its stakeholders within the area, (2) modern elite, consists of scholars, teachers, headmasters and retired government official, (3) religion elite, consists of head of Islamic-boarding-school and ustadz, (4) community elite consists of nongovernmental organization, youth leaders, women and even fisherman leaders. The results of the study provide an explanation of the relationship between the local bureaucracy with the local community, which was forming 4 (four) relationship models namely (1) Adaptive Model, (2) Accommodative Model, (3) Humanist Model, and (4) Tiered Elite Model. The most popular model of society is the Humanist model. Tiered Elite Model, on the other hand, creates pseudo harmony and put bureaucracy under the pressure of the hidden hand. There are three basic models and AAH model which consists of adaptive, accommodative and humanist is the preferred one. These four models can become theories in the context of a harmonious relationship between the government bureaucracy and society in the process of social and political change. These theories can be a source of inspiration in any social relationship that supports every harmonious social relationship.
\end{abstract}

Keywords: local government bureaucracy, adaptive, humanist, elite. 
Proceeding ICOGISS 2019

Page 820-837. ISBN: 978-602-6 988-75-1

Web Jurnal Online: jurnal.unmuhjember.ac.id

By: Indar Arifin

Analysis Of The Relationship Between Local Government Bureaucracy And Society Mode

In The Process Of Social And Political Change In Wajo Regency

\section{INTRODUCTION}

Local bureaucracy, in the post-reform era of democracy in Indonesia, has become a very important instrument to be studied, researched and analyzed in-depth and comprehensively. The reason underlying the importance of local bureaucracy is to achieve the goal of the Unitary State of the Republic of Indonesia (NKRI) so that the benefits of decentralization can be reaped. Decentralization becomes a very important execute political action to achieve democratic governance, that is, the people of the region are no longer merely objects of the power of the central government, but the subjects who will actively involve in achieving the share goals of the regions. Achieving shared goals in the regions requires good cooperation and collaboration with all elements at local government which involves three sectors namely, the government sector, the private sector and the civil society sector.

Government sector consist of government itself and all of its instruments, including the bureaucrats as the public servants. Bureaucracy becomes one of the most important elements in government. In this study, bureaucracy is defined as a governmental organization which controlled by the local government, not by the private sector, and operates based on local government's rules. People who works in bureaucracy called bureaucrats and given civil servant status (PNS/ASN) and paid from the local government's budget.

According to Weber (1947) and Durkhaem (1964), bureaucracy has associative cooperation style, not communal. As an organization, bureaucracy is characterized as a complex, detailed, and specialized institution. Its tasks are divided based on job' position, the roles within the organization are connected to one another, and there is no division could operate independently. Ndraha (2000) depicted organizations structure as human body which has its own anatomy, physical and characteristics, which centered in one place, called head. Similar to bureaucracy, top-level-position is called the head of bureaucracy, which controlled the lower divisions within the organization.

As an organism, organization can be classified as dynamic or static. When bureaucracy is considered as dynamic, the head of the organization has an essential role to lead the organization to achieve its goal and creates harmony among the members of the organization. However, when bureaucracy is seen as static, it has a function as a platform, a series of hierarchies, its jobs are divided job based on the roles and responsibilities.

Bureaucracy as public organization has several characteristics; serve the society by an obligation, not by like and dislike, non-profit oriented, not controlled by certain power, needs power when it comes to decision making because it is often under pressures from various parties (red: political pressures). Therefore, stronger power is needed in decision making processes.

The foundation of delivering public services is public interest. Maslow's theory (Sulisityani and Rosidah (2003) and Ndraha (2000) is still relevant to be used as a form of general human needs, for example (1) Basic physical needs, (eating, drinking, clothing, 
Proceeding ICOGISS 2019

Page 820-837. ISBN: 978-602-6 988-75-1

Web Jurnal Online: jurnal.unmuhjember.ac.id

By: Indar Arifin

Analysis Of The Relationship Between Local Government Bureaucracy And Society Mode

In The Process Of Social And Political Change In Wajo Regency

shelter), (2) Safety and Security, for example security, physical and non-physical guarantees, protection, stability, (3) Belonging and Social Needs (social needs) such as feeling of belonging to a group, friends, family feelings, friendship, (4) Esteem and Status, for example status, honor, appreciation, recognition, reputation, achievement, and (5) Self-actualization and fulfillment, for example the use of self-potential, self-development.

Bureaucracy is the answer to human tendencies to live within the society. Both Hegel (1953) and Weber (1958) defined bureaucracy as a national institution to answer the human's irrational while answering the complexities of community and governments relations. Bureaucracy' rationality required to resist the irrational thinking (for instance: magic and mystery) and enlightened human's work which put in order.

The bureaucracy's rational form which aspired by Weber and other pioneers cannot be separated from the framework of creating an order and harmonious society. Orderliness is made in such a way to maintain the existence of both internal and external parties of bureaucracy. If bureaucracy works under the state, according to Weber, the state is not to rationalize the ruling parties only, but at the same time to rationalize the people interest and not to dehumanize them (Beetham, 2000; Thoha 2002, Blau dan Marshall, 2000). Osborn and Tead Geabler (1996) argued that bureaucracy is not a crime which should be combat. In fact, bureaucracy is inherent needs for a state and people so the community far from savagery. Bureaucratic institution is a rational and civilized human guide, so it has a very strategic position and needs to be guarded by all elements. Bureaucracy cannot be seen as right and wrong. Bureaucracy must be seen through wisdom by trying to review and discuss it again, for the sake of the public interest. In order for the bureaucracy to remain active amidst sociopolitical changes, there needs to be continuous efforts made by various parties to find a formula for build harmonious relations both within the internal organization and the external environment.

Research conducted by Priyo Budi Santoso (1995) found that bureaucracy in Indonesia trapped in its past history throughout its local political culture, by which aristocrats puts king as the center of the universe and its bureaucracy as abdi dalem (red: palace maid). By this scheme however, bureaucracy at this point functioned as the king's servant and given the special privilege by the king so that its occupation, career, and position highly depend on the king whom appointed the bureaucracy itself. This happened from the era of Netherland to the Japan colonialism. The only change in bureaucracy in this era was just the name, from Abdi dalem to Priyai, to Pangreh praja to Pamong Praja. Centralistic authoritarianism that occurred throughout the reformation era is considered as Javanese local heritage and regarded as the absolute truth. In fact, the term of "republic" should emphasize that state elements could not stand by the elements of ruling parties. On the other hand, it should take a side for the people as the consequence of the term of "republic".

Similarly, research conducted by Syukur Abdullah (1985) on bureaucracy in South Sulawesi in the reformation era showed that there was a distortion by the meaning of state as a republic, because the state's development was top down and carried out by the ruling 
Proceeding ICOGISS 2019

Page 820-837. ISBN: 978-602-6 988-75-1

Web Jurnal Online: jurnal.unmuhjember.ac.id

By: Indar Arifin

Analysis Of The Relationship Between Local Government Bureaucracy And Society Mode

In The Process Of Social And Political Change In Wajo Regency

government by the power of bureaucracy from central to local region. The result of the research proved the ability of bureaucracy to play its role as an agent of change in top down development., Juanda Nawawi's research (2004) in Wajo regency also showed that local bureaucracy is just a tool for central government to understand local decentralization.

In Wajo regency, based on an empirical observation, interviews, and supported by data from various informant, bureaucracy in reformation era faces difficult transition due to the strong influence by the centralistic culture from the new order in spite of their autonomy' right through the principle of decentralization. Meanwhile, Wajo regency had a strong decentralization since $15^{\text {th }}$ century. Wajo's Political tradition and local government had a strong democratic value, which can be seen from its local governmental structure characterized by its similarity to parliamentary structure. The society and the government had a social contract. This contract is developed based on democratic principles where people are considered as the center of the power (unlike in Java's culture, Java culture puts the royal families as the center of the power) and the human rights were very detailed (bounded by the treaty). It is also important to note that the presence of To Manurung (people from the sky) did not happen in Wajo regency. The contract also indicates that the aspects of rationalization of To Wajoe had existed from hundreds years ago, similarly to the concept of Maradeka To Wajoe, najajiang alena maradeka, tanaimi ata,naiyya to makketanae maradeka maneng, ade assamaturusennami napopuang (Wajo's individuals are independent since they were born on their eternal land). The commoners of the land are all the free man, the laws are born by the mutual wills and controlled by them). This concept has been upheld by the Wajo's people until today. However, it cannot be actualized because of the centralistic power, especially since the new order era occurred. The presence of reformation could be the way to restore local democratic values in creating democratic and harmonious relationship between government, bureaucracy, and society.

Refers to the practice of decentralization in Wajo Regency, this research was derived and focused on government's local bureaucracy as the strategic institution in the middle of the community. This research is aimed at protecting the existence of bureaucracy as an important instrument in a modern democratic state.

The assumption of state as a public servant is certainly not as an institution of power that stands alone in the status quo which is authoritarian, but is still be placed in its capacity as an institution in democratic field. Bureaucracy is still expected to be an agent in every social and political change that occurs.

\section{STATEMENT OF THE PROBLEM}

What kind of relationship model between government local bureaucracy and its society in the process of social and political change (from centralization to decentralization system) in Wajo Regency? 
Proceeding ICOGISS 2019

Page 820-837. ISBN: 978-602-6 988-75-1

Web Jurnal Online: jurnal.unmuhjember.ac.id

By: Indar Arifin

Analysis Of The Relationship Between Local Government Bureaucracy And Society Mode

In The Process Of Social And Political Change In Wajo Regency

\section{OBJECTIVES OF THE STUDY}

To describe and to discover the pattern of the relationship between government local bureaucracy and its society in the process of social and political change (from centralization to decentralization system) in Wajo Regency.

\section{SIGNIFICANCE OF THE STUDY}

(1) To contribute to the intellectual insight towards the development of social science, specifically in public administration, which focuses on government local bureaucracy as the strategic element to achieve the state's goal through regional autonomy.

(2) To provide discussion platform in social sciences theory in order to increase scientific insight, especially in the field of good public administration through government local bureaucracy concept and social political change.

(3) To provide guidance for local government in desinging the relationship between government bureaucracy and community in each participatory political policy.

(4) To promote critical discussion towards the government and its bureaucracies as the dynamic space yet local-minded and be able to survive in the social and political change.

\section{RESEARCH METHODOLOGY}

Wajo Regency was chosen in this study because of its local values rooted from the local history which are Maradeka To Wajoe Adenami Na Popuang (Wajo's community are all the free people, only the laws will be followed). These values inclusively have relevance values which become the objectives of governmental democracy. This study chose government agencies which were closely related to the development of policy planning, namely: Regional Development Planning Board, Agriculture and Horticulture Agency, Information and Communication Agency, Industrial and Trading Agency, People Protection Office, Tanasitolo Subdistrict, Sabbang Paru Subdistrict, Tempe Nepo Village, Pajalele Village, Wage Village, Tadampalie Village, Sengkang and Sompe Administratif Office.

This was descriptive-quantitative research method. For the descriptive method, this research described, revealed, and analyzed the characteristics pattern in order to find the relationship between government and society model as an operational target for bureaucratic functions. The micro aspect of the study was the internal aspect of in the organization while the macro aspect was the social and political change, which analyzed using inductive method.

Related to the change analysis towards government bureaucracy as an organization, a research model called action research was applied. Data collections method was done by reviewing the literature and conducting field study. As the qualitative method, instruments used were Focus Group Discussion (FGD), intensive and systematic documentation, in depth interview, unstructured yet prioritized the process and results, acquired the data from the first hand (direct data), accentuate contextual details, using triangulation, prioritized emic perspective, which means prioritized correspondents' opinion rather than self-opinion, conducted a verification on cases that contradict with the correspondents purposively, 
Proceeding ICOGISS 2019

Page 820-837. ISBN: 978-602-6 988-75-1

Web Jurnal Online: jurnal.unmuhjember.ac.id

By: Indar Arifin

Analysis Of The Relationship Between Local Government Bureaucracy And Society Mode

In The Process Of Social And Political Change In Wajo Regency

snowball method until gained the required data. Qualitative data analysis is used by conducting data reduction method which considered relevant and representative by desplaying data displayed using matrix based on the theme and the needs. The final result of this study is a model that displayed in a chart.

\section{OPERATIONAL DEFINITION}

1) Government bureaucracy is an apparatus that works in a government organization on behalf of the government and the state, given civil servants status and received salaries and financial supports from state's budget.

2) Social political change is an attempt to rationalize which is conscious and structured which results in the change of the relationship between government and society, marked with the amendment of constitution and applied nationally, namely a change from centralization to decentralization.

\section{RESEARCH'S CONTEXT}

This study was used several philosophical social grand theories which relevant to the research as the basic for conducting literature study, which;

(1) Rational philosophy, creates a theory which believes that the truth is created through logical thinking (Hegel, Max Weber, Waldo and Wilson)

(2) Empirical philosophy, creates a theory which believe that the truth is stem from sensing and experience (Hobbes, Wallace, Weber, Osborn and Gaebler, Riggs, Linberg and Crosby, Ripley and Frenklin, Campbell and Marx)

(3) Positivism philosophy, creates a theory which believes that the truth is limited trough sensing (Comte, Durkheim, and Weber)

(4) Phenomenology philosophy, creates a theory which believes that the truth is created through human interpretive experience (Weber, Husserl, Heidegger)

\section{RESULTS OF THE STUDY}

The results of the study showed us that government bureaucracy and society relationship is able to create four relationship models; (1) adaptive-normative model, (2) accommodative arbitration model, (3) humanist imaging model, (4) tiered elite model. These four models could be described as follows:

\section{Adaptive Normative Model}

Adaptive Normative model is reflected in Wajo district regulation number 11 years 2014 on Participatory Development. This district regulation was formulated based on the agreement of all elements. In formulating the regulation, adjustment to the changing of political environment, which transform political system from centralistic to decentralization or top-down development planning mechanism to bottom-up mechanism, were made.

The issuance of participatory development regulation is considered as a blessing in promoting Wajo community's old principles which "free-man" principle. This principle, 
Proceeding ICOGISS 2019

Page 820-837. ISBN: 978-602-6 988-75-1

Web Jurnal Online: jurnal.unmuhjember.ac.id

By: Indar Arifin

Analysis Of The Relationship Between Local Government Bureaucracy And Society Mode

In The Process Of Social And Political Change In Wajo Regency

which is interpreted in Buginese philosophy as "maradeka to Wajoe", is considered as one of the momentums to raise the freedom values which existed in Wajo history in the $15^{\text {th }}-16^{\text {th }}$ centuries. Participatory district regulation is also considered as a momentum to unite the history understanding of To-Wajo'e (Wajo society) and to preserve regional integrity values. These values considered could bring systematic balance for both internal and external change in the globalization perspective through the lens of democratic government paradigm (good governance). The tendency to maintain this integration, in perspective of functional structural theory is recognized as one of the very important components. Integration mechanism can be used to maintain sustainability structural essential patterns by using adaptation method in order to minimize the diversity. In this regard, government has excellent understanding of the importance of normative adaptation in creating harmonious balance with its community.

Even though this harmonious balance do not fully occur, it is still recognized as a strategy in understanding social change for the government. This balance is really important to begin cooperative process with the community. It can be seen at the various parties' involvement in formulating participatory local regulations. These parties are scholars, nongovernmental organization (LSM), community leaders (Tomas), even an international organization (Usaid) contributing as the main pioneer of participatory local regulations. There is no unilateral works in participatory local regulations establishment after reformation era as the form of social and political change and as the prove of cooperative work process in adaptive normative model.

However, the success of the implementation of this is still questionable. According to various groups as a process of developing democratization leading to a systematic form of change, it is actually considered to be very adequate. In this case, the local government bureaucracy has a very important role as an agent of change, as a regulator and facilitator of change in the region, in the form of normative consensus and patterns, which have an adaptive value to the changes which are taking place.

The results also show that, normative consensus, actually does not mean there is no conflict. The conflict exists but it is not observable. It is veiled. In this perspective this normative consensus is an outcome of the conflict itself. This means that the Participatory Development Regulation is the result of the struggle of the people, to liberate from the oppression of the authorities, which is accompanied by aspects of legality that can protect the will to participate.Here, NGOs and academicians consider that the Regional Regulation on Participatory Development is the momentum for liberation from the power oppression that ever existed. In this context the freedom of the voice of the people becomes a tendency of the conflict struggle that exists in the balance "as if". Whereas in the context of conflict theory, the presence of external institutions such as USAID or NGOs and academicians is a significant agent of change.

This normative adaptive relationship model also shows that the strength of international institutions (Usaid) plays an important role indirectly by encourage community institutions, namely academics and NGOs, to change. 
Proceeding ICOGISS 2019

Page 820-837. ISBN: 978-602-6 988-75-1

Web Jurnal Online: jurnal.unmuhjember.ac.id

By: Indar Arifin

Analysis Of The Relationship Between Local Government Bureaucracy And Society Mode

In The Process Of Social And Political Change In Wajo Regency

This situation shows that the power of reform is in the external power of the government. While the power of government is regarded as a positive response from the owner of a large force. The government plays as a catalyst and facilitator in the process of renewal and change. Institutions such as Usaid, NGO groups, and academicians are seen as external parties of the government, and this is seen as a source of government energy in relation to the process of social and political change which occurs

This model named adaptive because it has an ability to adapt social and political change nationally even globally, while still adjusting with the local demands which came from the local history values. Moreover, it is named normative because this adaptation located in regulatory establishment through local regulations chapter 11 year 2004 which discussed participatory local regulations. For clearer insight about adaptive normative model, it is described in the chart below;

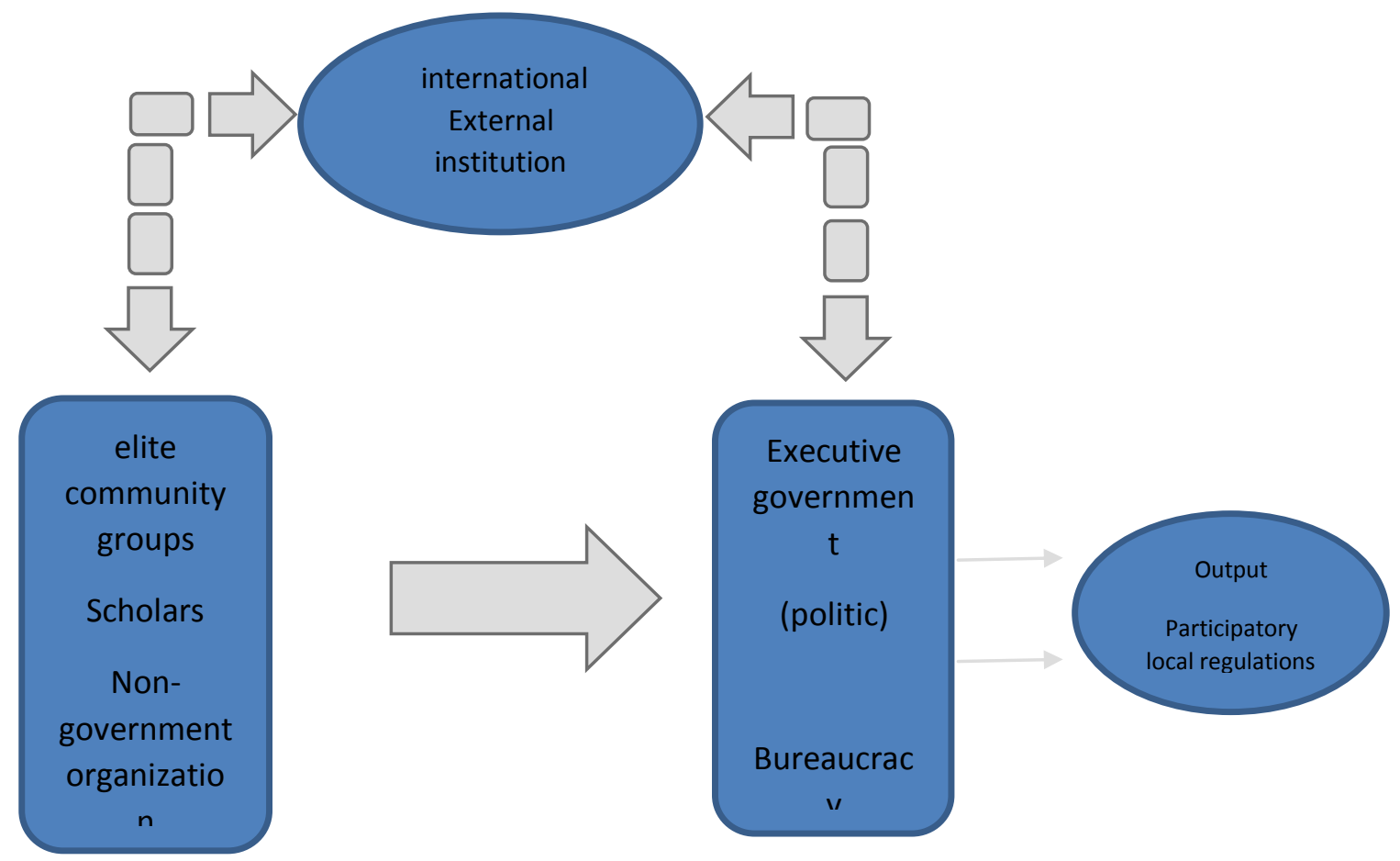

Picture: 1. Adaptive Normative Model 
Proceeding ICOGISS 2019

Page 820-837. ISBN: 978-602-6 988-75-1

Web Jurnal Online: jurnal.unmuhjember.ac.id

By: Indar Arifin

Analysis Of The Relationship Between Local Government Bureaucracy And Society Mode

In The Process Of Social And Political Change In Wajo Regency

\section{Accommodative Arbitration Model}

The relationship of accommodative arbitration can be found in $\backslash$ Tudang Sipulung (local conference). Tudang Sipulung can only be found in agricultural village typology. Meanwhile, villages with non-agricultural livelihood, Tudang Sipulung do not recognized as a development participatory model at grass root level.

However, Tudang Sipulung is can be recognized as a simple participatory model in agriculture community, while this model could not be found in the urban community, moreover, this model originally came from agriculture community's tradition.

In general, the term Tudang Sipulung is not used as a problem, but the values contained therein are generally deliberations for consensus. The relationship model that occurs is a relationship model that looks plain because it is more informal, and is related to habits that have become a tradition for generations

This aspect of tradition inherent in the Tudang Sipulung model makes this process a more accommodative associative model. This means the Sipulung Tudang is a mechanism which accommodates an imbalance among the interests of various parties in agriculture.

The accommodative value in this model is the individual process to adjust with the environment. On the other hand, accommodative intend to create synthesis of conflicting interests or understanding in order to create cooperation between individuals or groups.

It is also stated that the accommodative process in the Tudang Supulung is not a coercive accommodation. It can be interpreted as the accommodative arbitration model (more compromise accommodation), mediation (mediate, connecting, facilitate accommodation), or tolerance (form of accommodation without formal approval).

In most cases, accommodation values could be found at Tudang Sipulung model in each village studied. Unfortunately, this kind of models only functioned to agriculture's discussion which aimed at avoiding conflicts within the community and not reported to a court. Moreover, Tudang Sipulung involve social value, rather than law. Almost all of the values in this model prioritize synergetic kinship. Even though not all the farmers present at Tudang Supulung gave their opinion, the democratic value presented because they have spokesperson who usually school teachers in the village. The role of the teachers was meaningful because they are conveyed the farmers' aspiration. It can be seen that the ability and the courage to speak were not possessed by the grass root, so they still need other people to represent their opinion regardless of the freedom to use language mastered by the community used in Tudang Sipulung.

The role of the local chief as the village formal elite in the process of Tudang Sipulung is generally seen as mediator. The chief has charisma rather than other rational aspect, such as higher education. Agricultural facilitators also had a strategic position in Tudang Sipulung both as mediators and as motivators. However, this role does not exceed the strategic position of the local chief. In this context, the local chief could give a huge influence towards the Tudang Sipulung processes. If Tudang Sipulung becomes one of the social 
change instruments in the village, hence the local chief will occupy a strategic role as the agent of change.

However, Tudang Sipulung is not functioned in all of social change's instrument, it only occurred in the field of agricultural. The main point is that Tudang Sipulung is not socialized and is not even used as an instrument in other fields of decision making whilst agricultural community seen this as one of the relevant models in establishing good governance. Government Bureaucracy's direct roles, can only be found as the field agriculture instructor $(P P L)$ as the representative of the department of agriculture which spread out to villages. Meanwhile, the local chief as the political officials who are directly elected by the society can be seen as the direct bureaucracy which works as the representative of subdistrict head. As a result, it can be seen that the model of bureaucratic relation with the community model is manifested as mediator, motivator, even, and facilitator.

This relationship model is not occurred by force, but by the process of accommodation and meditation. This relationship model is explained through the chart below:
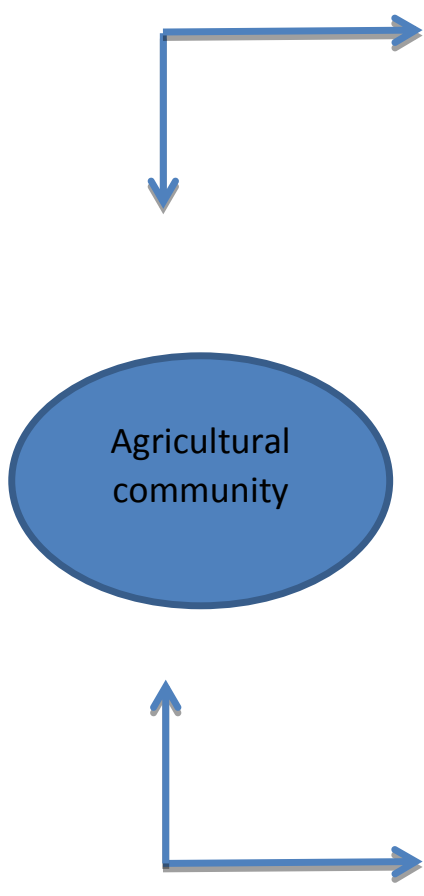
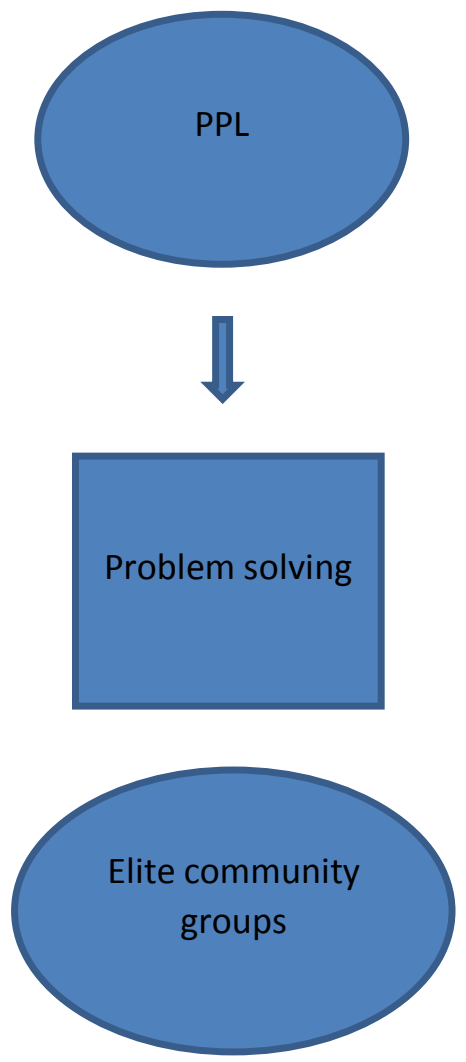

Picture 2. Accommodative Arbitration Model
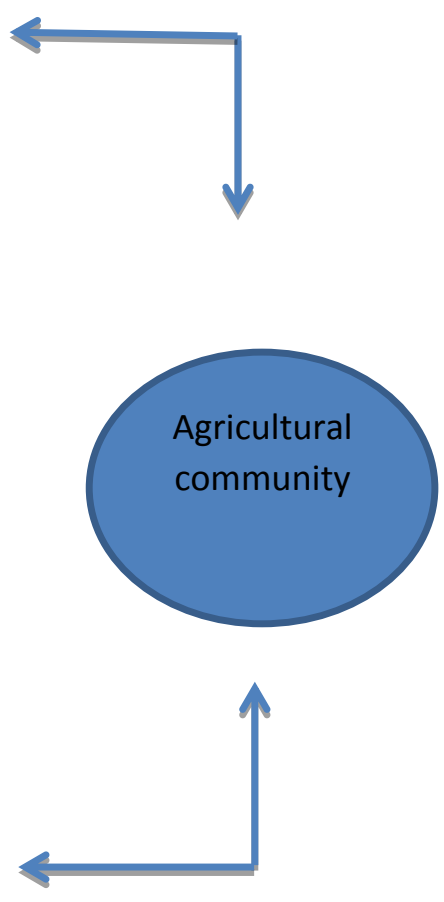
Analysis Of The Relationship Between Local Government Bureaucracy And Society Mode In The Process Of Social And Political Change In Wajo Regency

\section{Humanist Imaging Model}

This model is one of the rational models which is very popular among the communities because of its tendency towards independence aspect, which it can be seen in the process of extracting ideas during the process. The community is placed as the one who has desires for their village development. In this model, historical value is promoted as a model of change at grassroot level by understanding the social reality in the community as the main approach.

Understanding social reality becomes one of the main values which inherent to the process of extracting ideas. On top of that, government including its bureaucracy does not involve in this process except playing its role as motivator, facilitator, and regulator.

This approach by principle fights for a holistic approach and avoids deterministic thinking and the emancipation effort devoted by the community in their daily life. It is marked by extracting ideas model which always begins by exploring the history of human civilization the area concerned.

The main tendency that exists in the empowerment process is to put society in the main position in social change development. It is believed that every individual has the capacity to participate in development. To do so, it requires strong intention to explore their potential.
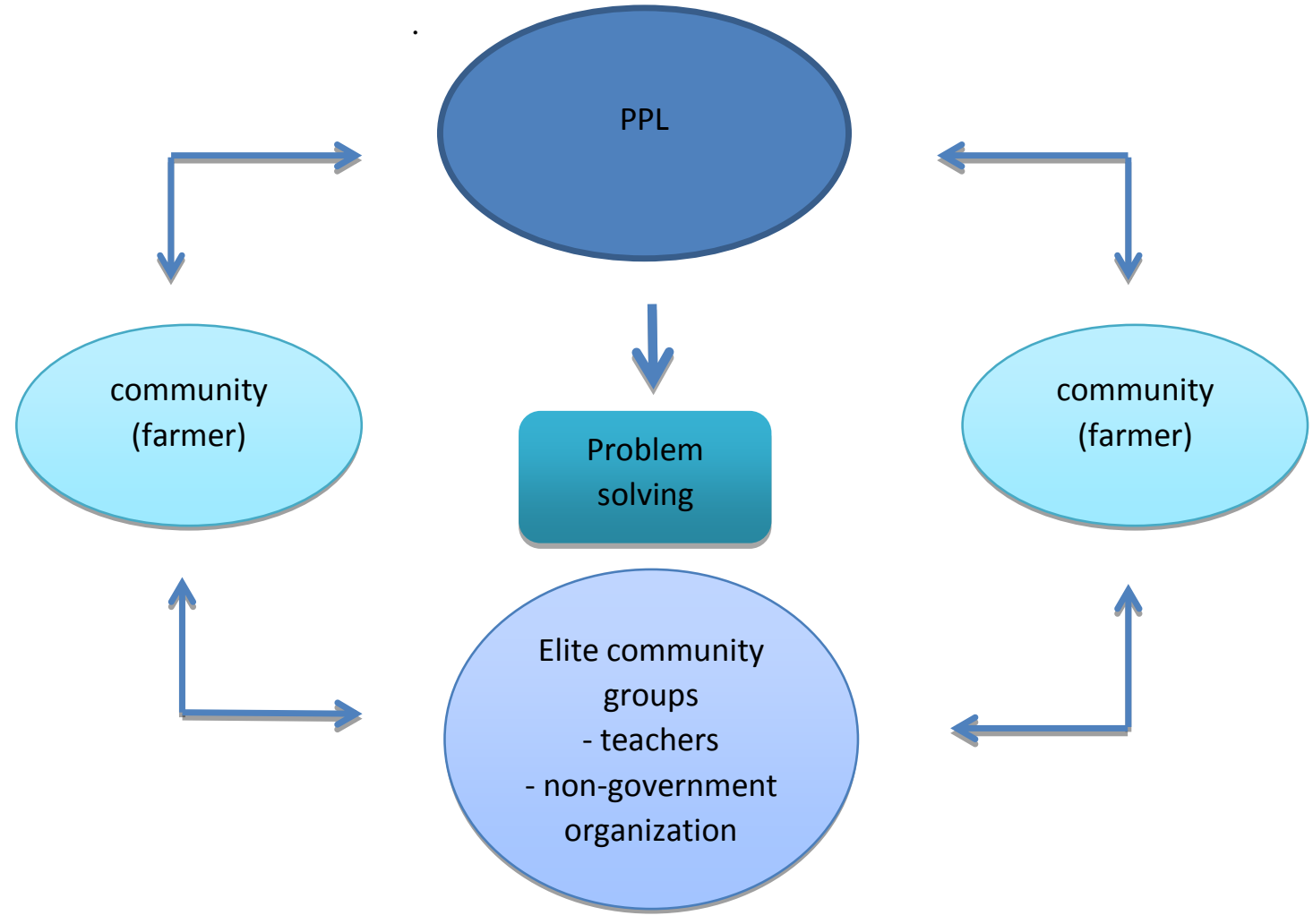

Picture 3. Accommodative Arbitration Model 
Proceeding ICOGISS 2019

Page 820-837. ISBN: 978-602-6 988-75-1

Web Jurnal Online: jurnal.unmuhjember.ac.id

By: Indar Arifin

Analysis Of The Relationship Between Local Government Bureaucracy And Society Mode In The Process Of Social And Political Change In Wajo Regency

The presence of international partnership institutions, is considered to have more capabilities in exploring community's participation compared to other empowerment models because of the higher independence and its rational and impersonality characteristics. It can be understood because the existence of international institution is an external existence which resides in beyond the interests of the object. Its personal interest is hardly found because the bearer of this instruments has absolutely no dependence on the target object. After the values are built within the community after the project, the institutions will leave the location, so there is no room to build various interests, like other internal institutions do.

It can be seen in the relationship model that partnership agencies had a tendency to prevent social engineering and mobilized development. Hence, it tries to bring the community to implement more humanistic social sciences paradigm with concentetion, which raise society's awareness of oppressive systems and structures which lead to dehumanization which kills human characters.It appears that counter hegemony efforts are carried over in this participatory model which tends to "humanize the human". This concept was explored through a participatory development approach through the humanist approach at the lowest level, namely the rural community as a target point. Awareness which built by partnership is critical awareness, which considers systems and structures as the source of the problem. The implementation structural approach is an effort to avoid blaming the victim system and to critically analyze social, political, economic and cultural structures and systems which have an impact on the state of society. The point is, the process of change which is built through paradigm tends to carried over by this partnership, namely building critical awareness of the community, with more transformative model of social and political change.

When the government (its bureaucracy) takes over the model because of the partnership program is in the end of the period, the value will not be the same as the partnership model by the international institution. The government appears to be not independence towards its implementation although they are trying to maintain its independence. It seems that there are hidden interests which difficult to avoid from both the community and the party who implementing it. 
For a better understanding, it described in the charts below;

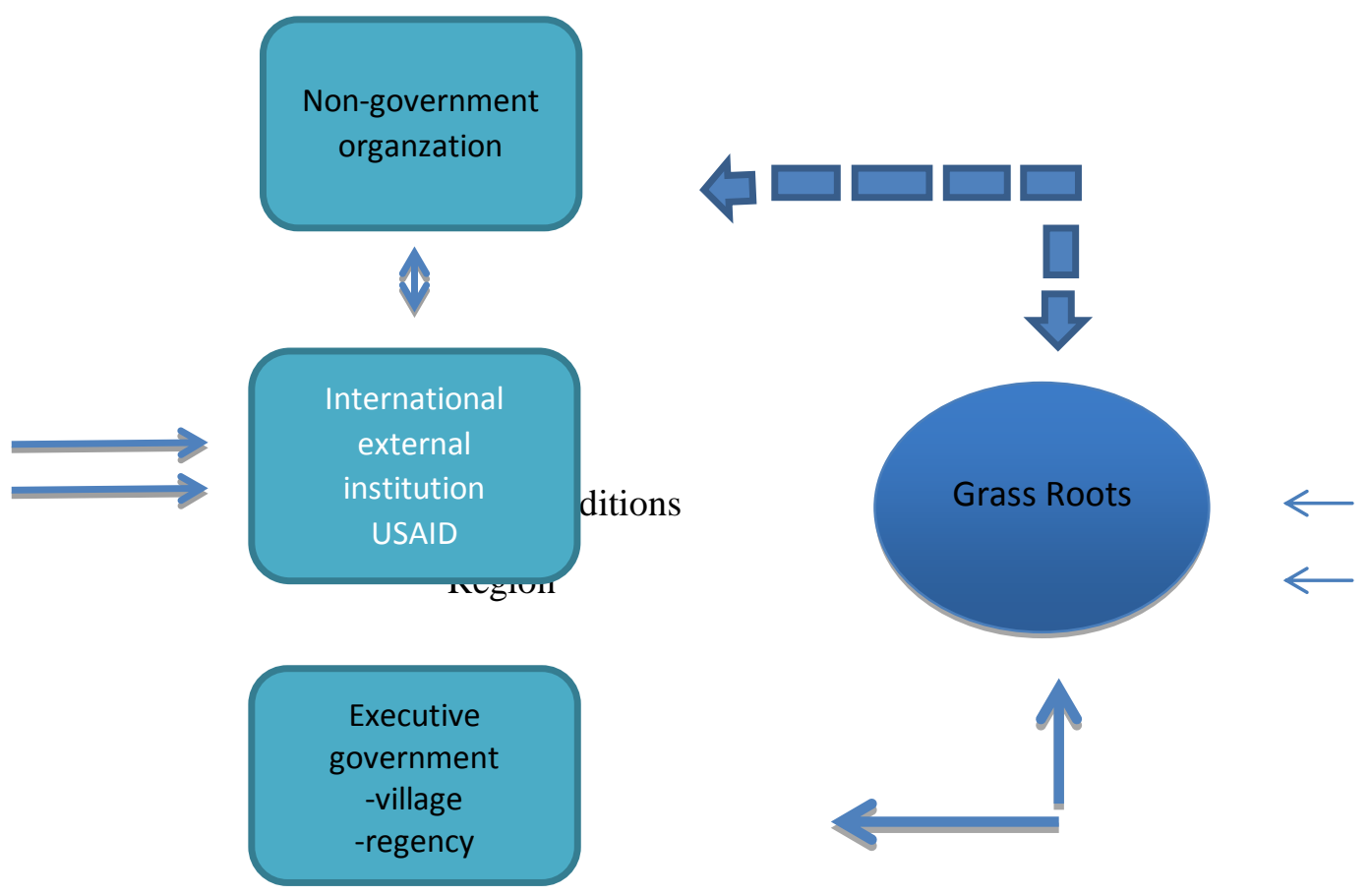

Picture 4. Humanist Imaging Model

\section{Tiered Elite Model.}

Multilevel which occurred through the national program named Muserambang in all of the element levels can be seen as the up down participatory pattern (vertical). Even though it is formatted in such a way, to maintain up down pattern model, but the model does not become the place for mobilization. However, this is difficult to avoid. From the structural aspect, it seems that the effort to work on bottom up paradigm is very clear, but in its implementation, the up down pattern is inevitable.

Government's bureaucracy as the executor of Musrembang project, tends to see the Musrembang as formality that must reach the targets and objectives with its legality instrument, the official reports. This condition is already left alone because the society already accustomed with this kind of situation. Therefore, it is not open conflict both from internal bureaucracy level and external bureaucracy level or the stakeholder. 
This pseudo harmony has negative implications on the relationship between the government bureaucracy and the community. People still assume that the relationship occurred in top down relationship model is worth to all participation (untrue participation). This pseudo participation makes the brand relationship as if there is harmony.

Hidden hand empowered in this level of relationship. Hence, it puts bureaucracy under pressure and the society will become an object of the so-called-harmonious relationship. For better insight, the relationship model is described by the picture below;

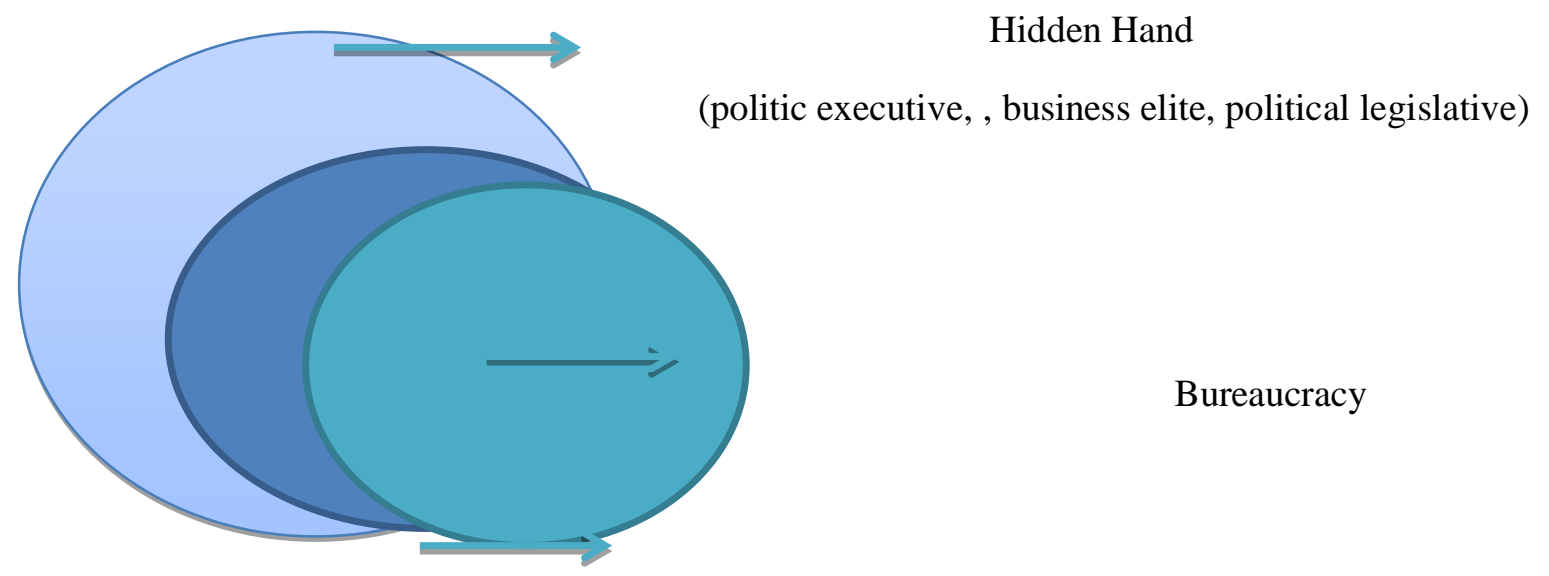

Society

Picture 5. Multilevel Elite Model 
Proceeding ICOGISS 2019

Page 820-837. ISBN: 978-602-6 988-75-1

Web Jurnal Online: jurnal.unmuhjember.ac.id

By: Indar Arifin

Analysis Of The Relationship Between Local Government Bureaucracy And Society Mode

In The Process Of Social And Political Change In Wajo Regency

\section{CONCLUSION}

What kind of relationship between government bureaucracy and society model in the process of social and political change in Wajo Regency?

The results of the study showed us that government bureaucracy and society relationship is able to create four relationship models; (1) normative-adaptive model, (2) accommodative arbitration model, (3) humanist imaging model, (4) tiered elite model

(1) Normative-Adaptive model determined by the establishment of participatory district regulation, which coherent with their local wisdom, always puts forward the aspect of formal legality in the form of regulations in order to interpret socio-political changes which occurred. The integration mechanism is used to maintain the integrity of essential structural patterns using adaption methods, in order to control the differences. It seems that the government in this adaptive model really understands the importance of normative adaptions in maintaining a harmonious balance in government, especially in the essence of its bureaucracy. This harmonious balance, although it will not be entirely implemented, will remain a strategy in understanding social change for government executors. This balance is very meaningful to begin a cooperative process with the community.

(2) Accommodative-Arbitration model

This model was found in Tudang Sipulung (local conference). It is only found in agricultural typology while the community's livelihood is not entirely in agriculture segment. Tudang Sipulung is not considered as participatory development model in grassroot level. However, it is still considered as a good connector. Bureaucracy considered as the mediator, motivator even facilitator.

\section{(3) Humanist Imaging Model}

This is the most society's favored rational model because of the independency aspect which appears in the process of extracting ideas during the process. The society is considered as the stakeholder of the development. Historical values are promoted as models of change at the grassroot level by understanding the society's social reality as the main approach. Unfortunately, this is only in the imaging model when the independent who conducted an assistance to society ends, the government will take over. However, the government is not fully independence in its implementation. Although maintaining its independence, hidden values which are very difficult to avoid both from the community and the implementing party are still there.

(4) Tiered Elite Model

This model implemented as part of national program named Musrembang which is conducted in every level of government. It looks as the up down participatory pattern (Vertical). The hidden hand Elite power is strengthened in this model. Hence, it puts 
Proceeding ICOGISS 2019

Page 820-837. ISBN: 978-602-6 988-75-1

Web Jurnal Online: jurnal.unmuhjember.ac.id

By: Indar Arifin

Analysis Of The Relationship Between Local Government Bureaucracy And Society Mode

In The Process Of Social And Political Change In Wajo Regency

the bureaucracy under pressure and the society placed as the smallest element and functioned only as an object within look-harmonious relationship.

Final conclusion by the model reduction result is that there are three basic external model which is AAH: Adaptive, Accommodative, and Humanist. These three models could become a theory in creating harmonious relationship of government bureaucracy and society model in the process of social political change. It is confirmed that the theory could become an inspiration in any kind social relationship to maintain harmonious social relationship in order to survive in the middle of social and political change.

\section{Recommendation}

1. Establishing a local regulation is essential as the Adaptive form towards social and political change

2. Local regulations socialization is required because it is the cooperation instruments.

3. Tudang Sipulung is marked as the important model for society's aspiration-delivery platform.

4. Openness to assisting external institutions should be promoted.

5. Wise and relevant local's value along with newest update of development must be examined deeply to strengthen region's existence.

6. The findings of this study should be adopted for region's development.

7. For further research, researchers should focus on examining legislative and executive relationship model in good governance and relate it with democratic values in Wajo regency. 
Proceeding ICOGISS 2019

Page 820-837. ISBN: 978-602-6 988-75-1

Web Jurnal Online: jurnal.unmuhjember.ac.id

By: Indar Arifin

Analysis Of The Relationship Between Local Government Bureaucracy And Society Mode

In The Process Of Social And Political Change In Wajo Regency

\section{Bibliography}

Abdullah, M.Syukur. 1985. Birokrasi dan Pemangunan Nasional: Studi Tentang Peranan Birokrasi Lokal dalam Implemntasi Program Program Pembangunan di Sulawesi Selatan. Unpublished. Ujung Pandang. Hasanuddin University.

Abdullah, M.Syukur. 1986. Birokrasi dan Pembangunan Nasional: Studi tentang Peranan Lokal dalam Implementasi Program-Program Pembangunan di Sulawesi Selatan. Unpublished. Hasanuddin University

Abidin,Zaenal. 1985. Wajo, Abad XV-XVI Suatu Penggalian Sejarah Terpendam Sulawesi Selatan dari Lontara. Bandung. Penerbit Alumni

Albrow, Martin. 1990. Max Webber's Construction of Social Theory. London. Macmilallan .1996. Birokrasi, (Terjemahan: M. Rusli Karim dan Totok Daryanto). Jogjakarta. PT.Tiara Wacana

Arifin, Indar. 2010. Birokrasi Pemerintahan dan Perubahan Sosial. Makassar. Pustaka Refleksi

Arifin, Anwar. 1986. Komunikasi dan Perubagan Sosial. Ujung Pandang. Kelompok Penulis Ikhtiar

Barzelay, Michaels. 1992. Breacking Trough Bureacracy, Berkeley, Los Angeles. Oxford. University of California Press

Blau, M.Peter \& Marshall W. Meyer, 1987, Birokrasi dalam Masyarakat Modern, (terjemahan oleh, Gary R.Yusuf) Jakarta UI Press

Bethan, David. 1990. Translation of:Sahar Simomora.) Jakarta. Bumi Aksara.

Bilhartz, Peter, 2002. Teori Teori Sosual: Observai Kritis Terhadap Para Filosofis Terkemuka(Terejemahan oleh Sigit Jatmiko). Yogjakarta. Pustaka Pelajar

Budi Santoso. Priyo. 1995. Birokrasi Pemerintahan Orde Baru, Perspektif Kultural dan Struktural. Jakarta. CV Rajawali

Dwidjowito. Riant Nugroho. 2000. Organisasi Publik Masa Depan, Redefinisis Peran Pemerintah Jakarta. PerPot.

Durkheim, Emilie. 1964. The Rules of Sociological Method. New York. Free Press . 2000. Otonomi Daerah: Desetralisasi Tanpa Revolusi. Jakarta. Elex Gramedia. 
Proceeding ICOGISS 2019

Page 820-837. ISBN: 978-602-6 988-75-1

Web Jurnal Online: jurnal.unmuhjember.ac.id

By: Indar Arifin

Analysis Of The Relationship Between Local Government Bureaucracy And Society Mode

In The Process Of Social And Political Change In Wajo Regency

2003 Reinventing Pembangunan: Menata Ulang Paradigma Pembangunan

Untuk Membangun Indonesia Baru dengan Keunggulan Global.

Jakarta. Elex media Komputindo.

Fay, Brian. 1991. Teori Sosial dan Praktek Politk. Jakarta. jakarta Pustaka.

2002. Filsafat Ilmu Sosial Kontemporer, (terjemahan: M.Muhith). Jogjakarta, jendela dan Tadarus.

Gertz, Cliggot. 1980. Abangan, santri, Priyai dalam Masyarakat Jawa (translated by: Aswib Mahasin) Jakarta. Pustaka Jaya.

Haris Syamsuddin dkk. 2000. Birokrasi dan Demokratisasi, Pengalaman Indonesia dan Thailand, Jakarta. PPW-LIPI

Hegel and Friedrick, George Wilhelm. 1953. Philosophie of Right. London. Oxford University Press

Karim Rusli. 1982. Seluk Beluk Perubahan Sosial. Surabaya. Usaha Nasional.

Khu, S.Thomas. 1970. The Structure of Scientefic Revolutions. Chicago. The University of Chicago Press

Lauer, Robert H. 2001. Perspektif Tentang Perubahan Sosial (Translated by; Alimandab). Jakarta. Rineka Cipta.

Mahardika, Timur. 2006. Strategi Membuka Jalan Perubahan. Bantul. Pondok Edukasi.

Mac Iver, Robert. 1954. The Web of Government. New York. The Macmillan Company 1955. The Modern State. London. Oxford University Press.

Muluk, Khairul. 2005. Desentralisasi \& Pemerintahan Daerah. Malang.

Nawawi, Juanda. 2004. Analisis Desentralisasi dan Kinerja Pelayanan Publik di Kabupaten Wajo, (Unpublished Dessertation). Makassar. Hasanuddin University

Osborn, Read Gablear. 1996. Mewirausahakan Demokrasi (Translated by: Abdul Sorsyid). Jakarta. Pustaka Binaman Apressido

Sutiastini, dkk. 2003. Managemen Sumberdaya Manusia, Konsep, Teori, dan Pengembangan dalam Konteks Organisasi Publik. Yogjakarta. Gaya Media

Thoha, Miftah. 2002. Perspektif Perilaku Birokrasi. Jakarta. Raja Grafindo Persada

Weber, Max. 1947. Essays in. New York. Oxford University Press

Weber, Max. 1958. The Methodology of The Social Science. New York. Free Press 